\title{
Fernando de Vera y el Panegírico por la poesía: a propósito de paternidades
}

\section{Fernando de Vera and the Panegírico por la poesía: On the Subject of Paternities}

\author{
Carmen Delgado Moral \\ Universidad de Córdoba
}

\section{RESUMEN}

El presente artículo analiza la biografía y producción literaria de Fernando de Vera y Mendoza, autor al que ya desde el siglo XVII le fue atribuida la autoría de un tratado sobre teoría poética titulado Panegírico por la poesía, aparecido en Montilla (Córdoba) el mismo año de la muerte de Luis de Góngora; las difíciles relaciones que este autor mantuvo con su padre, un personaje poderoso en la vida política de la España de ese momento histórico, nos han servido de base para justificar la anonimia de un texto marcado desde sus orígenes por la ambigüedad en su atribución.

Palabras Clave: Panegírico por la poesía, Fernando de Vera y Mendoza, conde de la Roca, anonimia, Montilla, teoría poética.

\section{ABSTRACT}

This article reviews Fernando de Vera y Mendoza's biography and literary production. From the seventeenth century the authorship of a treatise on poetic theory titled Panegírico por la poesía which appeared in Montilla (Córdoba) the same year as Luis de Gongora's death, was attributed to this writer. The difficult relations that he had with his father, a powerful figure in the political life of Spain at that moment in history, have been used as a starting point to justify the anonymity of a text marked from its origin by the ambiguity in its attribution.

Key words: Panegírico por la poesía, Fernando de Vera y Mendoza, Count of the Roca, anonymity, poetic theory.

\section{ATRIBUCIONES Y AUTORÍAS}

El Panegírico por la poesía se dio al molde en la ciudad de Montilla (Córdoba), en la imprenta de Manuel de Payva, en el año 1627. La obra aparecía anónima, lo cual dio lugar, ya desde sus orígenes, a toda una serie de conjeturas acerca de la identidad de su autor que se evidencian incluso en el 
propio Curtius (infra), quien, sin desvelar la personalidad que se escondía tras el anonimato, se refería solamente al «desconocido autor»; a pesar de que el problema aún no ha sido desvelado, debido en parte a los exiguos estudios derivados en torno a una obra cuya rareza bibliográfica ha ocasionado una escasa recepción del texto, la obra fue atribuida ya desde sus orígenes a Fernando de Vera y Mendoza, hijo primogénito del conde de la Roca.

\section{Una firma velada}

A pesar de que el Panegírico por la poesía había salido a la luz carente del nombre de su autor, el hecho de que en la portada de la obra figurase el escudo de la casa de los Vera, claramente reconocible por haber sido utilizado unos años antes en El Embajador (1620), obra de gran éxito, restringía su autoría a un círculo muy acotado por el entorno familiar del futuro conde de la Roca. El primer testimonio que atribuye la autoría del Panegírico por la poesía a Fernando de Vera y Mendoza se debe a Bernabé Moreno de Vargas, quien en su Historia de la ciudad de Mérida (1633) inserta en los preliminares un romance de dicho autor y lo incluye en el apartado correspondiente a «Escritores de libros»: «Don Fernando de Vera y Mendoça (...) escriuio vn Panegyrico en fauor de la poësia, y aunque en el callò su nombre, lo descubriò su ingenio, y la mucha erudiciõ que en el, y en otros sus estudios manifiesta» (1633: 324r). Otro de sus contemporáneos, el bibliógrafo y erudito Nicolás Antonio, lo citaba en su Bibliotheca hispana nova (póstuma, publicada en Roma en 1696) como autor del Panegírico por la poesía y de la Explicación y notas al Libro quarto del Arte común ${ }^{1}$. Juan Francisco Andrés de Ustarroz también señala su autoría en su Panegyrico sepulcral á la memoria póstuma de don Thomas Tamayo de Vargas (1642), y distingue al Panegírico de Vera como una de las obras en las que se destacaba la labor, en ese caso poética, de Tamayo de Vargas.

En el siglo XVIII son varias las obras que apuntan a Fernando de Vera como autor del Panegírico: en primer lugar, el Discurso II sobre las tragedias españolas $(1753)^{2}$ de Agustín de Montiano y Luyando, al que le seguirían los Orígenes de la poesía castellana (1754) de Luis José Velázquez³.

\footnotetext{
${ }^{1}$ «Ferdinandus de Vera, scripsit: Panegyrico por la Poesia. Montillae 1627. Explicacion, y notas al Libro quarto del Arte comun. Granatae 1631. in 8» (Nicolás Antonio, 1783: 393).

${ }_{2}$ «En Don Fernando de Vera se halla citada la Tragedia (8) de Dido, y Eneas, de Don Guillen de Castro, Autor bien conocido», y en la nota 8 se refiere al Discurso Apologetico de la Poesia impresso en Montilla año de 1627", de donde se colige que quizá no hubiese consultado la obra — puesto que no acierta en el título-, y que la paternidad de la obra a Fernando de Vera fuese ya conocida (Montiano y Luyando, 1753: 19).

${ }^{3}$ El autor cita tratados sobre poesía y retórica como el Arte Poética Castellana (1580) de Miguel Sánchez de Viana, el Arte para componer en metro castellano (1593) de Gerónimo
} 
Manuel Cardenal de Iracheta llama la atención sobre un testimonio contenido en un manuscrito de Luis José Velázquez de Velasco titulado Observaciones sobre las antigüedades de Extremadura de León (1754), en el que dicho marqués afirma haber visto el Panegírico en la librería del conde de la Roca y del que opina que «es muy importante para la historia de la poesía castellana» (Cardenal de Iracheta, 1941: 273).

Sin embargo, el autor que aporta la primera noticia extensa acerca de la personalidad del anónimo panegirista es Cayetano Alberto de la Barrera y Leirado en su Catálogo bibliográfico y biográfico del teatro antiguo español (1860), siendo el primero en adjudicar, aunque de manera incierta, el segundo apellido, Mendoza, a nuestro autor, descartando así la designación de la autoría a Juan Antonio de Vera, que había sido alegada hacía unos años por los traductores de la Historia de la literatura española de George Ticknor ${ }^{4}$. La Barrera se basa, por un lado, en los testimonios señalados de Nicolás Antonio y Montiano y Luyando, y, por otro, en la propia personalidad del conde de la Roca, cuya arrogancia no hubiera permitido el fracaso de esa primera edición apuntada en el prólogo, ni hubiese utilizado en el mismo ese tono humilde y sincero, más propio de una persona que durante toda su vida permaneció a su sombra (Barrera y Leirado, 1860: 468-471). No obstante, el conde de la Roca ocultaría su nombre en otras obras; Carmen Fernández-Daza apunta que este es el verdadero autor del Tratado del origen generoso e ilustre del linage de Vera (1617), que aparecía bajo del nombre del licenciado Velázquez de Mena, quien la dirigía a Juan Antonio de Vera y Zúñiga (Fernández-Daza Álvarez, 1995: 498); la obra trata de ennoblecer el apellido Vera, remontando su origen a la antigua Roma e incorporando datos que pertenecen al campo de la fantasía, y se detiene curiosamente en la figura de Juan Antonio de Vera, silenciando de este modo a sus hijos, el mayor de los cuales contaba ya dieciocho años. También se ha barajado la posible autoría de otro tratado genealógico de la familia Vera: Parentescos que tiene don Iuan Antonio de Vera y Zuñiga...con los Reyes Católicos, y otros principes y gran-

de Mondragón, la Philosofía antigua Poetica (1596) de Alonso López Pinciano, el Arte Poética Española (1592) de Juan Díaz Rengifo, el Cisne de Apolo de Carvallo, las Tablas Poéticas de Francisco Cascales, el Discurso sobre la Poesía de Pedro Soto de Rojas, etc., y a continuación pone en relación, por su juventud, sabiduría y erudición, las obras de Luis Carrillo de Sotomayor y Vera y Mendoza: «El libro de la erudición Poetica de D. Luis Carrillo publicado con sus Rimas en Madrid 1613. y el Discurso Apologetico en defensa de la Poesia, que compuso D. Fernando de Vera, acreditan lo mucho, que uno, y otro Autor havian leido en una edad mui corta; pues el primero lo escrivio antes de los 25 . años, y el segundo à los 16», si bien afirma que la Poética de Luzán es el mejor escrito en su clase (Velázquez de Velasco, 1754: 167-169).

${ }^{4}$ En la traducción al castellano de la Historia de la literatura española de George Ticknor, vol. II, con adiciones y notas críticas de Pascual de Gayangos y Enrique de Vedia: «D. Juan Antonio de Vera y Zúñiga, en su Panegírico por la poesía, obra rara y curiosa, (...)» (1851: 563). 
des señores (1627), que salió bajo el nombre de Pedro Fernández Gayoso, y aparentemente impreso en la ciudad de Arrás. La publicación de la obra coincidía curiosamente con una fecha crucial en la vida de Juan Antonio, ya que había sido nombrado vizconde de Sierrabrava, había heredado el mayorazgo de los Figueroa, había sido elegido por el conde de Olivares para escribir su biografía (los Fragmentos históricos de la vida de don Gaspar deGuzmán, Conde de Olivares) y, además, en abril de ese mismo año había nacido Fernando Carlos, el primogénito de su segundo matrimonio con su prima María de Vera y Tovar, con la que había contraído segundas nupcias en 1623. Igualmente, Il miglior giglio di Francia, una biografía de Luis IX de Francia (Lión, 1640), con una dedicatoria al conde-duque de Olivares y otra «a los estudiosos», aparecía bajo el seudónimo de Notoniano Vadin.

Las distintas genealogías citadas, además de otra aparecida en 1617 bajo el nombre de Sylva de Chaves, cuya autoría se ha atribuido a fray Fernando de Vera, obispo de Bujía y tío de Juan Antonio de Vera (Fernández-Daza Álvarez, 1995: 499-500), silencian los nombres de los primeros hijos del futuro conde de la Roca. Sin embargo, en un nuevo tratado genealógico aparecido en 1635 bajo el nombre de Francisco de la Puente, titulado Tratado breve de la antigüedad del linaje de Vera, sí se reconocían los hijos habidos del primer matrimonio del conde de la Roca. Su autor, probablemente otra vez el obispo de Bujía, alababa el apellido Vera, cuyo principio remonta a los orígenes de Roma; afirma que las distintas variantes del apellido Vera (Vere en Francia y Flandes, Verox en Inglaterra e Irlanda) vienen todos de un tronco común, «que es Numa Pompilio, Rey de Roma» (1635: 1-10) el linaje de Vera tuvo su origen hacía más de 2300 años. En España, retrocede sus orígenes a los emperadores Trajano y Adriano, y más adelante también al Cid. Cuando llega hasta Juan Antonio de Vera, su sobrino, le dedica las siguientes palabras:

Nació en Merida, à sido casado dos vezes, la primera con la señora doña Isabel de Mendoça, en quien tuuo al señor don Fernando de Vera y Mendoça, que con su entendimiento escogiò mas la vida Eclesiastica; como lo an hecho muchos hijos primogenitos de señores, y casó segunda vez el señor Conde con su madre de V.S. mi señora la Condesa de la Roca doña Maria de Vera y Touar, su prima, de su mesma casa, y sangre (...) (1635: 149v-150r).

${ }^{5}$ Ya en 1724, Franckenau (o Juan Lucas Cortés) había llamado la atención sobre la verdadera identidad que se escondía tras el nombre de Francisco de la Puente: «Don Frey Ferdinandus de Vera, Archi-Episcopus \& Cuzcensis Peruvianus, sub Don Francisci de la Puente Burgensis, Presbyteri Cuzcensis nomine Limae, Peruviani Regni Metropoli anno 1635» (1724: 118); en su obra también llama la atención sobre los dos hijos agustinos del conde de la Roca e Isabel de Mendoza, pero no se detiene en ninguno de ellos (206). Palau y Dulcet también apuntaría que «parece ser que Fernando de Vera es el autor de esta obra y no Francisco de la Puente», sin especificar que se trataba del obispo de Bujía, y no de Fernando de Vera y Mendoza. 
A pesar de que esta obra cita en dos ocasiones a Fernando de Vera (la segunda bajo el nombre de Fernando Luis de Vera y Mendoza, «presbytero»), silencia a su hermano Pedro Laureano, que ya había fallecido. El memorial lo dirigía al primogénito del segundo matrimonio del conde de la Roca, Fernando Carlos Antonio de Vera y Figueroa (de tan solo ocho años), y se ilustraba con el escudo de la familia Vera, idéntico al que había aparecido en la portada del Panegírico por la poesía.

Quizá basándose en los datos aportados por La Barrera, Aureliano Fernández-Guerra y Orbe atribuye también la paternidad de la obra a Fernando de Vera y Mendoza (1864: 12). Menéndez Pelayo, en su Historia de las ideas estéticas en España (1883-1889), incluye el Panegírico entre las poéticas de los siglos XVI y XVII, junto al Libro de la erudición poética (1611) de Luis Carrillo y Sotomayor y el prólogo de Alonso de Valdés al frente de las $\mathrm{Di}$ versas Rimas (1591) de Vicente Espinel, entre otros discursos.

El primer autor que realiza un estudio crítico del Panegírico por la poesía es Ernst Robert Curtius (1939; 1955: 760-775), quien analiza la trayectoria del discurso panegírico, las bases cristianas de la teoría poética presentes en la obra y su aportación en el establecimiento de los fundamentos ideológicos del arte antiguo en el Siglo de Oro. Alberto Porqueras Mayo ofrece asimismo un estudio de los aspectos más relevantes de la obra y la sitúa entre los ejemplos más significativos de la tradición panegírica española (1989: 29-37).

Desde la editio princeps de 1627 no se realizó ninguna edición del Panegírico por la poesía hasta 1886 , fecha en que se realizó una edición a plana y renglón de doscientos ejemplares a expensas del marqués de Jerez de los Caballeros, Manuel Pérez de Guzmán y Boza. En 1941 Manuel Cardenal de Iracheta publica una tercera edición en la Revista de Bibliografía Nacional y realiza un sucinto análisis de la obra y sus problemas de autoría. La última edición conocida es de 1968; Homero Serís realiza un estudio introductorio en el que destaca la importancia de la obra, ya señalada previamente por Curtius, Menéndez Pelayo, Muiños Sáenz y Cardenal de Iracheta; en este caso el texto es reproducido de forma facsimilar a cargo del editor Antonio Pérez y Gómez.

\section{Comentarista de Nebrija y admirador de Lope: autoría en cuestión}

Muy diferentes son las tres únicas obras que se conservan bajo la también incierta autoría de Fernando de Vera y Mendoza. Se trata de dos obras dirigidas a la enseñanza de la gramática de Antonio de Nebrija, tituladas Explicación i notas al Libro quarto del Arte... (1631) y Explicacion i notas al Libro Quinto... (1631), además de una comedia titulada No hay gusto como la honra. La primera de ellas la recoge Nicolás Antonioy la segunda Palau y Dulcet. En ellas se hace un comentario de los libros IV (sobre la sintaxis y el orden de las palabras en nuestro idioma) y $\mathrm{V}$ (sobre métrica y prosodia) 
de la primera gramática castellana, según le enseñó al autor su maestro, el padre Agustín de Herrera, de la Compañía de Jesús, como indica el propio Vera. Son obras, no obstante, muy diferentes al Panegírico por la poesía, y no encontramos en ellas ningún punto de confluencia con aquella ${ }^{6}$, incluso en lo atinente al estilo; es por ello por lo que Cardenal de Iracheta — con el que coincidimos en la opinión- puso en tela de juicio la atribución de estas obras al mismo Fernando de Vera, autor del Panegírico y de los versos preliminares contenidos en la citada Historia de Mérida de Moreno de Vargas, basándose en el hecho de que las obras, de una clara finalidad didáctica, ligadas muy probablemente a un uso docente, se basan - como el mismo autor indica en el prólogo - en las enseñanzas de su maestro, el jesuita Agustín de Herrera (1941: 277-279), y por ello en la portada se reproduce el escudo de la Compañía de Jesús. Las obras contienen esta vez todos los requisitos de censura. La licencia otorgada al «L[icenciado] Fernando de Vera Presbytero» para la impresión de la Explicacion i notas al Libro Quinto la concede por delegación el vicario del arzobispado de Granada, y la aprobación de la misma la firma el rector del Colegio de la Compañía de Jesús de Granada. No tenemos constancia de que Fernando de Vera estuviese en Granada en 1631, pero, aunque así hubiese sido, nos resulta difícil creer que, siendo agustino, y dada la rivalidad existente en la época entre los colegios pertenecientes a las distintas compañías religiosas, publicase una obra diseñada y dirigida a colegios de los jesuitas ${ }^{7}$. Por otro lado, la primera noticia que atribuye la comedia No hay gusto como la honra a Fernando de Vera se debe a Cayetano Alberto de la Barrera, quien incluyó dicho título en su Catálogo bibliográfico y biográfico del teatro antiguo español bajo el nombre de Fernando Luis de Vera y Mendoza y con una entrada diferente a la correspondiente al autor del Panegírico (1860: 568), por lo que probablemente pensara que se trataba de otro autor. Sin embargo, pensamos que estamos ante una obra del mismo autor ${ }^{8}$. Posteriormente, Ramón de Mesonero Romanos citó esta comedia en Dramáticos posteriores a Lope de Vega (1859: 41).

${ }^{6}$ En esta ocasión, la ostentación que suponía la aparición en portada del escudo nobiliario de los Vera ha sido sustituido en la segunda de las obras por un magnífico grabado (de Nicolars Lauwers) de una sagrada familia en un fértil entorno recordando el huerto del Edén descrito en el Génesis, al que le sigue, ya en la portada, el escudo de la Compañía de Jesús.

${ }^{7}$ Abraham Madroñal destaca la relación existente entre la abundancia de comentarios de la Gramática de Nebrija y los factores económicos derivados de la implantación de determinados textos para la enseñanza en los centros escolares, los cuales eran realizados por los mismos docentes que impartían la materia. Ello dio lugar a una deturpación del texto de Nebrija, derivada en gran parte por los problemas que sus herederos tenían con el privilegio de impresión (2009: 46-48). El propio Agustín de Herrera publicó en 1633 un comentario al libro IV (también con grabado de Nicolars Lauwers) bajo el seudónimo de Diego López.

${ }^{8}$ Recordemos que Francisco de la Puente (o sea, su pariente Fernando de Vera, obispo de Bujía) lo mencionaba en dos ocasiones en su memorial sobre el linaje de los Veras, cada una con un nombre diferente, Fernando y Fernando Luis 
La comedia se publicó de forma póstuma y fue inserta en la Parte treinta y vna de Comedias nueuas escritas por los mejores ingenios de España (1669) junto con otras obras de autores como Antonio Hurtado de Mendoza, Tirso de Molina, Juan de Zabaleta, etc. La obra pone en escena a unos personajes nobles que se desenvuelven en medio de un conflicto de honor, cuyo origen se basa en los celos provocados por un equívoco que da pie al enredo, al más puro estilo calderoniano. Sin embargo, su contenido, e incluso su título, debe mucho tanto a una comedia de Juan Pérez de Montalbán titulada No hay vida como la honra, de gran éxito en su tiempo, como a la comedia Primero es la honra que el gusto, de Francisco Rojas Zorrilla.

En definitiva, podemos claramente observar que estamos ante obras cuya naturaleza dispar dificulta el que puedan aglutinarse bajo el nombre de un mismo autor. Nos inclinamos hacia la opinión de que los versos preliminares a la Historia de la ciudad de Mérida, así como la comedia No hay gusto como la honra, cuya composición refleja una mano no demasiado diestra en la versificación, son obra de un mismo autor, Fernando de Vera y Mendoza, y que este es asimismo el que subyace al anonimato del Panegírico por la poesía. Razones de amistad con Moreno de Vargas, por un lado, y admiración por Lope de Vega y su escuela, en el caso de la comedia, sirven de base para la atribución de estas dos obras, además del hecho claramente constatable de que fuesen publicadas bajo el nombre de Fernando (o Fernando Luis) de Vera y Mendoza. Sin embargo, en lo referente a los dos opúsculos gramaticales, aun habiendo sido publicados con el nombre de Fernando de Vera, nos inclinamos a pensar que estos debieron de ser producto de algún autor homónimo, o tal vez un seudónimo manejado por el propio Agustín de Herrera.

A continuación se ofrece una sucinta biografía de Fernando de Vera y Mendoza, en la que se atiende con especial detenimiento a las difíciles relaciones paterno-filiales entre el panegirista y su progenitor, Juan Antonio de Vera, desavenencias familiares que propiciaron en parte - y esta es nuestra tesis de partida- la anonimia de la obra y la consiguiente confusión por parte de la crítica en la atribución del opúsculo.

\section{Filiaciones}

\subsection{Una conflictiva relación familiar}

En 1599 nacía en Sevilla Fernando de Vera y Mendoza, hijo primogénito de Juan Antonio de Vera y Vargas, futuro conde de la Roca. Corrían tiempos de penurias y escasez, ya que recientemente había aparecido un nuevo brote de peste bubónica, que se prolongaría hasta el año 1601 (Domínguez Ortiz, 1986: 17). La ciudad del Betis sufre en estos años un período recesivo de su economía, provocado tanto por razones exógenas, como es el desastre que 
conlleva la epidemia de peste, como endógenas a su propia economía, como resultaba de la existencia de un mercado laboral muy poco flexible, que le impedía competir con el que ya se vislumbraba como un nuevo monstruo de las importaciones: China, que comenzaba a imponerse en el mercado americano (García Fuentes, 1997: 113-114) ${ }^{9}$. El desastre provocaba una ralentización de las tasas de crecimiento de la economía sevillana - hasta entonces tan pujante-, con la consiguiente inflación de los precios que, a su vez, provocaba una inseguridad en las relaciones comerciales con las Indias, ya que los grandes almacenistas habían impuesto precios desorbitados a sus productos, originándose una burbuja especulativa que ponía en riesgo el mercado financiero, que no podía hacer frente al pago de los préstamos. Como indica Lutgardo García, esta situación persiste aun en 1605, año decisivo - como veremos- en la infancia de Fernando de Vera.

En medio de este ambiente poco óptimo para la alegría y los negocios, había nacido Fernando de Vera, hijo de un joven y ambicioso noble y de una sevillana perteneciente a una familia acomodada dedicada precisamente a la actividad mercantil con el tráfico de Indias $^{10}$. De orígenes extremeños, la familia de Juan Antonio de Vera se había trasladado a Andalucía (primero a Jerez de la Frontera y unos años más tarde a Sevilla) cuando este apenas contaba cuatro años. Fue en Sevilla donde Juan Antonio conoció a Isabel, hija de Pedro de Mendoza y María de la Fuente, una familia de ricos comerciantes. No debió de ser muy grato a su padre, el capitán Fernando de Vera y Vargas, que su hijo concertase por su cuenta matrimonio con esta doncella, no mirando sino su placer, en lugar de la honra de su familia. El descontento del padre procedía del hecho de que su hijo hubiese convenido enlace con persona ajena a su grupo social - los Mendoza pagaban el impuesto de la blanca de la carne, claro signo de su falta de hidalguía-, pero mucho más del desconocimiento del origen de Pedro de Mendoza - lo cual era motivo harto sospechoso en una sociedad tan vinculada al linaje- $-\mathrm{y}$, especialmente, de la indudable procedencia judía del apellido de La Fuente ${ }^{11}$.

\footnotetext{
${ }^{9}$ En palabras de Antonio Domínguez Ortiz, «el ayuntamiento sevillano estaba al terminar aquella centuria en estado de quiebra», hecho que la Corona intentará paliar en parte con emisiones de deuda pública (1999: 19-31).

${ }^{10}$ Para el esbozo de los datos biográficos de Fernando de Vera incluidos en esta sucinta biografía, sigo muy de cerca las aportaciones de Carmen Fernández-Daza Álvarez incluidas en su libro El primer conde de la Roca (1995: 92-101) y en su artículo «Noticias inéditas de la vida de fray Fernando de Vera y Mendoza»(1994).

${ }^{11}$ Esto ya no era una mera sospecha, sino que era un hecho claramente constatable la presencia de este apellido en las listas de la Inquisición, siempre referentes a procesos de judaísmo, así como el auto de fe sevillano contra el doctor Constantino de la Fuente, relajado en estatua, acusado en 1500 de luteranismo y de posesión de un taller clandestino de imprenta (Fernández-Daza Álvarez, 1995: 47; Gil, 2000: 1: 342). Otros conversos sevillanos fueron Rodrigo de la Fuente, veinticuatro y contador de Sevilla, y su hijo Gonzalo de la Fuente, emparentados con otros conversos toledanos (los Zapata), y Alonso de la Fuente (Gil, 2000²: 26, 438).
} 
Quince años tenían tanto Juan Antonio como Isabel cuando esta dio a luz a Fernando en $1599^{12}$ en la colación de San Nicolás, y un año más tarde nació su hermano Pedro Laureano. En 1605 Isabel ya había fallecido. Desconocemos la razón de tan prematura muerte, pero lo que sí sabemos es que entre 1600 y 1605 la ciudad hispalense se vio acometida por la enfermedad del carbunclo anginoso, conocida popularmente como garrotillo, una especie de angina que también atacó a Plasencia, donde los Vera tenían familia (Villalba, 1802: 21, 32-35) ${ }^{13}$. Esta muerte, al igual que años más tarde la de su hermana Marina de Mendoza, resultaron harto ventajosas para sus respectivos maridos (Juan Antonio y Alonso Tello, unidos por una estrecha amistad), que se verían al fin redimidos de su error juvenil y facultados para poder concertar nuevos matrimonios, esta vez más ventajosos y sin menoscabo de su honra ${ }^{14}$.

Huérfano de madre y sin el sustento de la familia materna (tras el fallecimiento de sus abuelos), Fernando de Vera creció en Sevilla, donde se contagió de la inclinación que su padre sentía hacia la poesía, cultivada en sus ratos de ocio y exhibida con orgullo en cenáculos y academias. Ya desde muy joven Juan Antonio despuntaba como un joven poeta, y prueba de ello es la publicación de una de sus epístolas en la primera parte de las Flores de poetas ilustres (1605) de Pedro Espinosa ${ }^{15}$. Quizá por estas fechas Lope de Vega conoció las aptitudes para las letras de Fernando, al que sin duda conocía dada la íntima amistad que le unía al futuro conde de la Roca, y por ello no duda-

${ }^{12}$ Carmen Fernández-Daza reproduce la partida de bautismo de Fernando de Vera, fechada el 19 de agosto de 1599 (1994: 101). No eran ciertas, por tanto, las hipótesis de La Barrera y otros autores que daban como fecha de nacimiento el año 1603.

${ }^{13}$ Ya desde 1605 había constancia de la existencia de tratados médicos dedicados a esta enfermedad del garrotillo. Andrés de León escribió la obra Práctico de morbo gállico... (1605). En 1613, Cristóbal Pérez de Herrera publica la obra Brevis et compendiosus tractatus et essentia, causis notis, praesagio, curatione, et precaucione faucium et gutturi anginosorum, ulcerum morbi suffocantis garrotillo hispane apellati... En 1615 se publicarían varias obras, entre ellas De gutturis et faucium ulceribus anginosis, vulgo garrotillo, de Alonso Núñez de Lerena. Desconocemos si Isabel de Mendoza murió de esta enfermedad, pero, teniendo en cuenta que en ese mismo año de 1605 fallecían sus padres, resulta lógico pensar que se vieran afectados por alguna enfermedad de tipo contagioso. Manuel Cardenal de Iracheta, siguiendo el testimonio de Franckenau, daba como fecha del fallecimiento de Isabel de Mendoza el año 1620 (1941: 271 y 280).

${ }^{14}$ Marina había contraído matrimonio con Alonso Tello de Guzmán en 1601. Entre Alonso y Juan Antonio se estableció una íntima amistad, que perduró incluso durante la estancia de aquel en México como corregidor. Fernando de Vera recordaría a su tío en el catálogo de autores contenido en el período decimotercero del Panegírico por la poesía.

${ }^{15}$ Entre el círculo de amistades de Juan Antonio se encontraban amigos comunes a Pedro Espinosa, y que este incluyó en su famosa antología, entre ellos Baltasar del Alcázar, Juan de Jáuregui, Francisco de Rioja, Juan de Fonseca, Francisco de Calatayud, Antonio Ortiz Melgarejo, etc., y a los que Fernando de Vera incluyó en su catálogo de autores (si es que este no fue idea -o incluso obra- de su padre). Sobre Pedro Espinosa y su relación con los poetas del grupo sevillano, véase Molina Huete (2003: 139-140). 
ría en rubricar la aprobación del Panegírico por la poesía en una primera edición proyectada para ser impresa hacia 1620 (y que no vio la luz), trámite burocrático del que Fernando de Vera hace gala en los preliminares de la edición definitiva de $1627^{16}$.

Fernando tuvo como tutor a Alonso Gómez Blanco, del que recibiría una formación inicial basada fundamentalmente en el estudio de las lenguas clásicas, la gramática y la retórica, esta última un instrumento esencial no solamente para los que aspiraban a iniciarse en el mundo de la política, en el que el sagaz Juan Antonio ya había puesto sus ojos, sino también para los negocios (Olmos Gómez, 2010: 327-333), puesto que uno de los requisitos básicos de un buen mercader consistía precisamente en expresarse con soltura y habilidad, así como discutir con inteligencia e ingenio. Fernando de Vera tuvo a su alcance todo un mundo de relaciones sociales del más alto prestigio dentro del más selecto ambiente sevillano. Es por ello por lo que, cuando elabora su catálogo de autores en el período decimotercero de su Panegírico por la poesía, incluye un número considerable de poetas relacionados con el círculo sevillano, con los que su padre - y probablemente también el propio Fernando- compartiría reuniones y pláticas literarias.

Fernando de Vera adquirió durante su adolescencia una sólida formación humanística basada en un amplio bagaje de lecturas que procedían tanto de la biblioteca familiar como de otras bibliotecas nobiliarias que frecuentó, siguiendo su clara vocación literaria, aprovechando ese mundo de relaciones privilegiadas que le concedía su apellido. Entre ellas, destacó la del condeduque de Olivares ${ }^{17}$, pero también la del duque de Alcalá, con la que el pri-

${ }^{16}$ Del infructuoso intento editorial tenemos noticia en la aprobación que fray Juan de Vitoria, catedrático de escritura de la Universidad de Osuna, realiza para la edición de 1627, en la que leemos: «(...) los años passados vio, y aprouo este mismo papel Lope de Vega Carpio, y se dio al molde, con nombre del Autor, si bien no tuuo efeto, por la desconfiança del acierto, mas digna del mas discreto» (Vera y Mendoza, 1627: 2). Al igual que su padre, Fernando de Vera debió de admirar a Lope de Vega; de hecho, el Panegírico por la poesía tiene algunos puntos en común con la «Cuestión sobre el honor debido a la poesía», epístola dirigida a Juan de Arguijo, que el Fénix había incluido en sus Rimas (1602).

${ }^{17}$ Es conocida la afición de don Gaspar de Guzmán por las letras y por la búsqueda de nuevos ingenios en la Sevilla de principios del siglo XVII. Será precisamente ese amor a la cultura (que había heredado de su abuelo, el primer conde de Olivares) el que le valdría el sobrenombre de Manlio (Marañón, 1998: 56). Esto motivó el que su nombre y su figura fuesen objeto de veneración en la dedicatoria de más de un centenar de libros, cuyos autores buscaban el legítimo auxilio de un buen y valioso mecenas. El propio conde de la Roca confiesa a propósito de Olivares el que este quemase sus versos en 1626, previendo que las plumas más mordaces criticarían sus versos juveniles; Gregorio Marañón recogía en su clásica biografía del valido los últimos versos conservados de Olivares (549-550). Vera y Mendoza conoció otros versos perdidos de don Gaspar —destruidos, según Marañón (191), por el propio Olivares gracias a su buen gusto por las artes-, que probablemente compartiría con sus amigos del círculo sevillano; Vera los califica como «milagrosísimos» en el período decimotercero del Panegírico, una muestra de la subjetividad en la valoración que realiza el panegirista. 
vado rivalizó por conseguir una de las mejores bibliotecas privadas de Espa$\tilde{n} a^{18}$. También debió de frecuentar el joven Fernando las bibliotecas de los que fueron protectores de su padre: el duque de Medina Sidonia —destacado mecenas-y el duque de Béjar ${ }^{19}$, así como de muchos de los nobles a los que cita al final de su Panegírico: el marqués de Alenquer, el príncipe de Esquilache, el duque de Veragua, el duque de Híjar, etc.

Fernando compartió algunas de las amistades de su padre, entre las que se contaban los poetas de la escuela sevillana de Fernando de Herrera (Francisco de Rioja - al que conoció cuando era bibliotecario de Olivares ${ }^{20}$-, Juan de Arguijo, Francisco Pacheco, etc.) y otras figuras destacadas de su tiempo, como Tomás Tamayo de Vargas, Fernando Dávila o Francisco Morovelli de Puebla, a muchos de los cuales conoció por su estrecha relación con el conde-duque de Olivares. El número de sus amistades literarias fue tan amplio que de algunos no conocemos prácticamente más que lo poco que él nos ha transmitido con su Panegírico, como es el caso de Juan de Rojas o Jacinto Coronel - ambos ausentes en los catálogos de autores contemporáneos a este autor.

Como Pérgamo en el siglo II a. C., Sevilla también deseaba convertirse en la «Nueva Roma» ${ }^{21}$; como Atalo II, las grandes personalidades sevillanas (entre ellas Olivares) soñaban con poseer la mejor biblioteca y en ella contener lo más preciado de la cultura grecolatina y del saber humanístico; de ahí ese afán de recuperación constante de los clásicos y ese interés de los nuevos

${ }^{18}$ Muestra de su erudición y amor a la cultura es su magnífica biblioteca. Del catálogo de Alaejos y Angulo se deduce que Olivares era un excelente bibliófilo; su biblioteca albergaba en 1620 la elevada cifra de 1400 manuscritos y 2700 impresos, por lo que se contaba entre las más copiosas de las de la Europa de su tiempo (Marañón, 1998: 213). Para la relación del privado con el círculo sevillano de Francisco Pacheco, véase la biografía de Elliot (1998: 53-61).

${ }^{19}$ Aunque fue uno de los mecenas de su padre, y gracias al cual este consiguió el hábito de Santiago, el duque de Béjar destaca por ser la principal ausencia del catálogo de autores del período decimotercero del Panegírico. Quizá la tan conocida tacañería de este personaje, que fue motivo de decepción para Cervantes, lo fuese también para Juan Antonio, quien pudo sugerir a su hijo que silenciara su nombre.

${ }^{20}$ Sobre la estrecha relación de Rioja con Olivares, surgida en torno a los años en que Juan Antonio tejía lazos de amistad con personajes influyentes en la política y la cultura (en torno a 1607 y 1615), puede consultarse la introducción de Begoña López Bueno a la Poesía de Rioja (1984: 21) y la obra de R. A. Stradling titulada Felipe IV y el gobierno de España, 1621-1665 (1989: 438-439).

${ }^{21}$ Término acuñado por Vicente Lleó Cañal, quien analiza el arte, la historia y la literatura de la Sevilla del siglo XVI como manifestación de un estilo de vida heredero de la antigua Roma, de ahí el título de su obra Nueva Roma: mitología y Humanismo en el Renacimiento sevillano. El autor equipara el valor de la actividad artística de Sevilla con la de los otros grandes centros de la cultura renacentista (1979: 205). Sobre la conexión con el maquiavelismo, puede consultarse el artículo «Maquiavelo y el tacitismo en la España de los siglos XVI y XVII» (1993) de José María Martín Ruiz. 
autores por superarlos, pues, como decía Juan Antonio de Vera en El Embajador (1620), y como manifestación palpable del proceso de receptio del tacitismo en el siglo XVII, «por los exenplos passados adivine los fines, i las traças de los pressentes; porque como dixo Tacito: Otros son los onbres, pero no son otras las costumbres» (1620: 100v).

Fernando acompañó a su padre a algunos de sus viajes a la corte, donde probablemente tomó contacto con algunas de las bibliotecas madrileñas más ilustres. En alguna de estas bibliotecas manejó un cartapacio que contenía un manuscrito de fray Luis de León, con algunos versos compuestos por el propio rey Felipe II, según se colige de sus propias palabras: «Y en vn cartapacio manuscrito (que llegó a las mias) del Maestro Fray Luys de Leon, estauan por de su Magestad otros (...) y lo he cõprouado con el mismo papel en la librería de vn Cauallero Preuendado de Seuilla» (1627: 47). Los continuos viajes de su padre acompañando a sus protectores (el duque de Medina Sidonia y el de Béjar), así como la prisión que aquel sufrió entre 1613 y 1614, provocaron que Fernando, junto con su hermano Pedro Laureano, creciese sin el afecto de un marco familiar. Cuando en 1615 fallece en Mérida su abuelo paterno, este sentencia a través de sus disposiciones testamentarias el futuro de la joven promesa de tan solo dieciséis años; buen conocedor de los antecedentes maternos del primogénito de su hijo, marcados por la impureza de la sangre, un lastre con el que cargaría de por vida y que lo apartaría del ejercicio de cualquier actividad política de alguna relevancia, el testador vislumbró que lo mejor para los dos hermanos era sin ninguna duda el servicio a Dios $^{22}$. Es por ello que solicitaba a su primo, fray Fernando de Vera, obispo de Bujía, que recogiese a su nieto en su compañía, pero ni siquiera le dejaba una pensión por alimentos, siendo el primer vástago de su primogénito ${ }^{23}$. El futuro del joven Fernando ya estaba decidido, y mucho más el de su hermano. Sin embargo, como veremos, Fernando no se conformará con esta decisión: se le estaba asignando el tratamiento de un segundón, y él probablemente tenía mayores aspiraciones y pretendía seguir el modelo de su padre.

Desde 1505 existía una legislación específica que regulaba la transmisión de los mayorazgos, plasmada en las Leyes de Toro, luego reunidas en la Nueva Recopilación; dicha legislación otorgaba al primer nacido, a propósito de la transmisión de la propiedad, los derechos que la ley concedía al primogénito en línea recta descendente, por lo que teóricamente Fernando se convertía, por

\footnotetext{
${ }^{22}$ La carrera eclesiástica fue el designio que muchas de las familias bien posicionadas económicamente eligieron para sus vástagos; en el siglo XVI muchos de los prelados sevillanos procedieron de familias conversas, pero los requisitos de acceso al alto clero fueron endureciéndose a medida que avanzaba la centuria por ese temor incontrolado que se tejió en torno al judío y sus descendientes, y que se unió a una propaganda feroz que aniquilaba cualquier atisbo de humanidad sobre la raza (Gil, 2000: 2: 62-64).

${ }^{23}$ El codicilo del testamento de Fernando de Vera y Vargas, otorgado ante el escribano Juan Romo de la Rúa, el 11 de junio de 1615, lo transcribe Carmen Fernández-Daza (1995: 89).
} 
derecho propio, en el segundo heredero de la herencia de su abuelo paterno - el primero era, por supuesto, su padre-, por delante de sus tíos y otros ascendientes. Y es que la primacía dependía única y exclusivamente del nacimiento, y no de las preferencias familiares; esto era, al menos, en la teoría, y Fernando manifestó desde muy pronto su firme decisión de que aquella no se trocase en la práctica.

Los deseos testamentarios de su abuelo fueron cumplidos de inmediato, a expensas de los intereses y deseos del joven Fernando, y Juan Antonio pudo ver en la obediencia a su padre una solución para el futuro incierto de sus hijos más que una intromisión paterna en los designios de su nieto.

La relación de Fernando con su padre debió de ser fría y distante ${ }^{24}$, y en su decisión de ingresar a sus hijos en la vida religiosa debieron de influir motivos económicos, mezclados con el ansia de recuperación de su menoscabada honra. Y es que en su deseo de contraer nuevas nupcias, esta vez con persona de mayor alcurnia, esperaba obtener un nuevo sucesor que heredase su cuantioso mayorazgo, relegando a los hijos habidos de su primer matrimonio a una situación que rayaba el más absoluto olvido. Por ello Fernando fue enviado al convento de los agustinos en Antequera. La elección de esta ciudad para la realización del noviciado no deja de ser sospechosa, ya que desde finales del siglo XVI Antequera se había convertido en cuna y refugio de judíos y judeoconversos ${ }^{25}$; pero además, este enclave malagueño se revelaba como un importante foco cultural, que prestaba particular atención a los estudios de humanidades. Desde principios del seiscientos existía una cátedra de Gramática y Latinidad, que ocuparon personalidades tan importantes como Juan de Vilches o el mismo Francisco de Medina; este ambiente erudito propiciaría el nacimiento del grupo antequerano-granadino, con poetas tan destacados como Pedro Espinosa (López Bueno, 2006: 149) ${ }^{26}$ —autor de una de las mejores antologías del Siglo de Oro, las Flores de poetas ilustres (1605),

${ }^{24}$ Francisco Núñez Roldán analiza ese complejo mundo de las relaciones familiares en la Sevilla del Siglo de Oro en La vida cotidiana en la Sevilla del Siglo de Oro (2004: 125 y ss).

${ }^{25}$ A lo largo del siglo XVI, Antequera se había convertido en una de las ciudades más ricas de Andalucía debido a su intensa actividad comercial; fue precisamente ese esplendor el motivo principal por el que la ciudad se convertiría entre finales del XVI y principios del XVII en refugio de judíos y judeoconversos, muy frecuentemente ligados al mundo de las finanzas y al tráfico mercantil. Lorena Roldán Paz ha estudiado el aumento del control de las visitas inquisitoriales de inspección, muy relacionadas con el hecho que hemos destacado, en el artículo «Control de conciencias en la periferia: visitas inquisitoriales a la ciudad de Antequera en el siglo XVII» (2004). El convento de San Agustín, situado en la colación de San Sebastián, fue construido entre 1550-1556, y en el tiempo en que estuvo Vera aún estaba en proceso de remodelación.

${ }^{26}$ Pedro Espinosa es el autor de dos obras que llevan el título de Panegírico: el Panegírico de la ciudad de Antequera con las medallas halladas en ella (compuesta en 1626 en 1629) y el Panegírico al excelentísimo señor don Manuel Alonso Pérez de Guzmán (1629). No sabemos si la elección de estos títulos tuvo alguna inspiración de la obra de Vera, o viceversa, 
en la que Juan Antonio de Vera había publicado sus primeros poemas- o Luis Barahona de Soto, y compilaciones como la conocida con el rótulo de Cancionero antequerano (1627-28), una manifestación del interés por la poesía también entre los lectores del entorno. Tras un año de noviciado en el citado convento, Fernando regresó a Sevilla, donde juró sus votos en el convento de San Agustín de Sevilla ${ }^{27}$, tan solo un año después del fallecimiento de su abuelo paterno y de que se hubiesen firmado sus designios a voluntad de aquel testador. Su ingreso en el oficio queda recogido en el libro de profesiones del citado convento:

En el año milésimo sextésimo decimosexto (...), el hermano Fernando de Vera, hijo legítimo de don Juan de Vera y de doña Isabel de Mendoza, su esposa legítima, de la ciudad hispalense, tomo profesión y prometo obediencia a Dios omnipotente y a la santa Virgen María y al santo nuestro padre Agustín (...) y vivir sin propiedad y en castidad, de acuerdo a la regla de nuestro padre Agustín, hasta la muerte $(\ldots)^{28}$.

Pero, pese al juramento de sus votos, Fernando no estaba dispuesto a plegarse a la voluntad paterna. Solo y desamparado en el convento sevillano, sin duda muchas de sus plegarias irían destinadas a pedir venganza contra su maquiavélico progenitor, quien de esta manera disfrutaba enteramente de su mayorazgo, de la herencia que el abuelo materno había dejado a su nieto y, además, limpiaba su honra relegando a su hijo al más absoluto anonimato ${ }^{29}$.

pero lo que sí es sabida es la relación entre el antequerano y la familia Vera; en 1625 Pedro Espinosa se trasladó a Sanlúcar de Barrameda, lugar en el que el duque de Medina Sidonia, pariente lejano y protector de Juan Antonio de Vera, le había concedido una capellanía. Por una carta publicada por Fernández-Daza (1995: 95) conocemos que en el convento de los agustinos del Puerto de Santa María permaneció un tiempo uno de los dos hijos del conde de la Roca (sin especificarse su nombre), y que a ambos les unió - por su vínculo con el padreuna gran amistad, quizá debido en gran parte al nexo que desde siempre había unido a la casa de Medina Sidonia con los cristianos nuevos (Gil, 2000: 1: 24 y 42). Según Dámaso Alonso, Antequera se convirtió en el primer tercio del siglo XVII en uno de los focos culturales más importantes de España, y el porcentaje de poetas en relación con su número de habitantes era muy superior a cualquier otra ciudad del país (1950: 12).

${ }^{27}$ En palabras de Madoz, el convento de San Agustín de Sevilla, «casa grande de agustinos calzados», «llegó á ser uno de los magníficos conv[entos] de Sevilla, tanto por su estensión, comodidad, hermosura, cuanto por los patronatos y enterrenamientos que en él se encontraban (...)», y muy rico en obras de arte. Para el citado autor «los hijos de San Agustín fueron modelo de virtud, y entre ellos se contaban hombres científicos y profundos literatos» (1849: 323).

${ }^{28}$ El texto en latín lo transcribe Carmen Fernández-Daza (1995: 94). La traducción es nuestra.

${ }^{29}$ Una prueba de que Juan Antonio siempre vio a sus hijos como una pesada carga y un impedimento para su ascenso en la escala social es el hecho de que tan pronto como vio a sus dos hijos recluidos en un convento, él inició una larga carrera de obstáculos para conseguir su sueño de contarse entre la más perlada aristocracia, que comenzaría con la petición del hábito de Santiago en septiembre de 1616 — tan solo unos días después de que fray 
Fernando se vio inmerso en un mundo austero y riguroso, alejado de los debates y las tertulias, dedicado a la meditación y sometido a unas normas y unos sacrificios para los que él no había nacido; probablemente no estaba acostumbrado a madrugar, y aun menos para cantar en el coro, y no estaría dispuesto a renunciar al amor humano por el divino. Su naturaleza díscola y su absoluta falta de vocación religiosa quedaron patentes en el pleito que entabló para la obtención de la nulidad de sus votos.

Fue precisamente en ese año de 1616, con tan solo diecisiete años, y coincidiendo con la entrada en el convento sevillano, cuando escribió — si damos crédito a sus propias palabras incluidas en el prólogo- el Panegírico por la poesía. Cuatro años más tarde, en 1620, intentó imprimirlo en Sevilla, pero la aventura editorial se dio al traste, quizá por ese pleito contra el ejercicio de su profesión que él mismo había iniciado y que aún persistía. Nuestra hipótesis nos hace pensar que el hecho de que ese primitivo Panegírico se escribiese a una edad tan temprana pudiera estar directamente vinculado - en lo que coincidimos con Gabriel Calvo (1993) - con una finalidad puramente pragmática, como pudo ser la realización de un mero ejercicio escolar, que luego pudiera haberse aprovechado para el lucimiento personal en alguna de las academias a las que su padre era tan asiduo.

Fracasado en su empeño de alcanzar la renuncia de su profesión, en 1622 Fernando ingresa definitivamente, y hasta el fin de sus días, en la orden de San Agustín, y renueva sus votos en Madrid, en el convento de San Felipe el Real, retractándose del prolongado litigio que tantos sinsabores había ocasionado tanto a él como a su familia:

En 18 de noviembre (1622). Fray Fernando de Vera y Zúñiga (...), habiéndose cumplido el año de su aprobación en el convento de antiguos padres agustinos, hice profesión de acuerdo a la regla del santo padre Agustín, en el año 1616, el día 8 de agosto. Después, por otra parte, por su fuerza, virtud y valentía, teniendo dudas, en presencia del ordinario de Sevilla, hubiera iniciado un pleito por su nulidad en el cual perduré hasta este tiempo. Ahora, sin embargo, alejándome en mi propósito de este pleito espontánea, voluntaria y libremente, ratifico aquí mi profesión hecha en otro tiempo $(\ldots)^{30}$.

A raíz de esta decisión, las relaciones con su padre debieron de reanudarse; en 1626, Juan Antonio pudo ayudarle a retocar algunos pasajes del Panegírico por la poesía, donde aquel vio la oportunidad de incluir a muchos de sus amigos y alabar al admirado conde-duque. Y es que su objetivo no era

Fernando jurara los votos eclesiásticos- y culminaría en 1628 con la obtención del condado de la Roca gracias a su actividad como diplomático y militar y, especialmente, a su íntima amistad con el privado de Felipe IV.

${ }^{30}$ El texto latino lo transcribe Manuel Cardenal de Iracheta (1941: 272), quien lo toma a su vez — como él mismo indica- del P. Gregorio de Santiago Vela (1915: 154; FernándezDaza, 1995: 99). Hemos optado nuevamente por la traducción. 
otro que conseguir un título nobiliario que le posicionase entre la más acrisolada nobleza, y la publicación del Panegírico, con dedicatoria al citado valido, podía formar parte de ese guion de propaganda trazado por Olivares, que pretendía proyectar una imagen pública de esplendor de la monarquía hispánica desde todos los ángulos (político, económico, cultural...) ${ }^{31}$. La obra se publicó anónima, y posiblemente en ello también tuvo que ver mucho la opinión del futuro conde de la Roca: el que había condenado a sus hijos al olvido no podía consentir que el nombre de Fernando apareciera en una portada, ostentando el escudo de la familia Vera. Es por ello por lo que quizá se llegó a una solución intermedia que contentase a ambos, ya que probablemente Fernando amenazaba a su padre con dejarlo nuevamente en evidencia a través de la interposición de un nuevo pleito, esta vez contra su persona. La obra se publicó, por tanto, sin nombre de autor, pero con el escudo de la casa nobiliaria, cosa que, por otro lado, no debió de disgustar a Juan Antonio, pues ello daba lugar a la ambigüedad, ya que - tal y como ocurrió- muchos serían los que atribuirían la obra a él mismo. La aprobación de la obra el 29 de enero de 1627, así como el lugar elegido para la impresión de la misma (realizada el mismo año), se adecuarían a tamaña decisión. Justamente cuando Fernando vio cumplido su deseo de ver en letras de imprenta su primera obra, inicia un nuevo litigio, esta vez contra su propio padre, al que no perdonaría jamás el triste destino que le había reservado. Como señala Carmen Fernández-Daza, a la luz estaba que el pleito — sobre la teneduría del mayorazgo de los Acevedos - estaba perdido de antemano, pero eso era lo de menos, ya que lo que verdaderamente importaba es que su nombre saliera a la luz pública.

En 1633 Fernando de Vera vivía en Mérida, ciudad en la que en esa época se realizaban gestiones para el establecimiento de la orden de los agustinos (Lozano Bartolozzi, 1997), y allí publicó un romance en los preliminares de la Historia de Mérida de Bernabé Moreno de Vargas. Años más tarde, cuando contaba algo más de cuarenta años, se le acusa poco menos que de galanteador de monjas del convento de la Concepción de Mérida ${ }^{32}$. Precisa-

${ }^{31}$ El discurso panegírico ha estado de común muy ligado — desde sus inicios en Claudio Claudiano- a la obra realizada por encargo para una posterior lectura pública, de ahí su conexión con la oratoria y el arte de la retórica. Pedro Ruiz Pérez señala como rasgo inherente al género un estilo grandilocuente como cauce de la erudición, que se enmarca en ese proceso de reivindicación de la lengua vulgar que iniciara Nebrija (Ruiz Pérez, 2003). Sobre la pervivencia del panegírico como fenómeno ligado a la literatura de circunstancias y su vinculación con el mecenazgo en el Siglo de Oro, puede consultarse el artículo de Mercedes Blanco titulado «El Panegírico al duque de Lerma como poema heroico» (2011).

${ }^{32}$ Carmen Fernández-Daza publica una carta en la que Francisco de Quevedo, visitador de la orden de Santiago, se interesaba por las críticas que habían supuesto las visitas de Fernando al convento de la Concepción, y solicitaba informes que le sirvieran de prueba (1995: 100). La literatura de la época refleja esta figura del galanteador de monjas, íntimamente ligada a la de la monja desesperada que ya inmortalizara la pluma de Alfonso de Valdés en su Diálogo de Mercurio y Carón (1528). Para las familias bien posicionadas eco- 
mente en esa fecha la vicaria del citado convento emeritense era Isabel Moreno de Vargas, hija de Bernabé Moreno de $\operatorname{Vargas}^{33}$, regidor de Mérida, con la que Fernando podía tener una amistad precisamente por la relación con su padre, quien años antes había incluido en su Historia de Mérida el citado romance. La denuncia, con una finalidad claramente difamatoria contra su persona, fue admitida a trámite y se hicieron gestiones para averiguar si los hechos que se le imputaban eran ciertos o producto de la imaginación popular. De las investigaciones realizadas por el licenciado Diego Montano, basadas en una interrogación a veintisiete personas relacionadas con los citados conventos y la ciudad de Mérida, se deduce que dichas acusaciones eran infundadas, pero, aun así, Juan Antonio de Vera debió de ver en este hecho un nuevo motivo de deshonra familiar.

A lo largo de su dilatada vida conventual, Fernando no pudo obtener ningún puesto de relevancia, a pesar de los intentos del conde de la Roca. La impureza de su sangre, que había marcado su triste destino desde una edad tan temprana, también obstaculizó que alcanzase ningún cargo eclesiástico o puesto de relevancia dentro del convento, donde está claro que se observaban grados, y cuyo ascenso requería la aprobación de unos requisitos de limpieza de sangre ${ }^{34}$, a los que se sumaba un problema económico para aquellas familias que no estaban dispuestas — como era el caso— a sacrificar su hacienda en beneficio de los intereses de sus hijos; y es que — como señala Juan Gil— la información sobre la limpieza de la sangre resultaba cara, pues al iniciarse a instancia de parte, se imponía como una prestación coactiva y, por tanto,

nómicamente, el convento era la salida más rentable para colocar a las hijas solteras (Martínez de la Vega, 1994). Las cortes de Madrid de 1563 prohibían que los frailes residieran en los monasterios de monjas atendiendo a dos motivos: el primero se refería a una cuestión de carácter económico (puesto que mermaban la hacienda a las religiosas) y el segundo, y principal, se refería a razones de índole moral (ya que este hecho atentaba contra la imagen pública de las monjas); por ello, se establece que este tipo de visitas se hagan por las redes, sin entrar en los monasterios, y que no duraran más de diez días (una forma de evitar el popular galanteo); vid. Actas de las Cortes de Castilla: contiene las de Madrid, celebradas el año 1563 (1861: 327-328). Sobre los controles inquisitoriales que, tras el dictado de dicha normativa, se derivaron a causa de las denuncias por el escándalo que en numerosos casos provocaron las visitas de los frailes a los conventos, vid. Sánchez Ortega (1992: 152). Por otro lado, Bernardo José García García analiza la vida conventual en el Siglo de Oro, con sus frecuentes visitas y el trato de las religiosas con seglares, en su obra El ocio en la España del Siglo de Oro (1999: 20).

${ }^{33}$ Las contribuciones de la familia de los Vargas en la fundación de los conventos emeritenses fueron considerables, especialmente en el siglo XVII. Bernabé Moreno de Vargas (1576-1648) dedica unas páginas de su Historia de la ciudad de Mérida al convento de la Concepción (en el capítulo X «De los Conuentos, y Ermitas de Merida»), en el que profesaban sus hijas Isabel y Olalla (Moreno de Vargas, 1633: 309-310). Precisamente fue Isabel Moreno de Vargas una de las monjas llamadas a declarar como testigo de la investigación abierta contra Fernando de Vera, quien, dada su amistad, negó cualquier atisbo de intención deshonesta en el acusado y se limitó a alabar su conversación erudita. 
era el candidato (o su familia) el que debía correr con los gastos ocasionados por toda esa burocracia administrativa necesaria para la averiguación de los verdaderos orígenes — cuya responsabilidad, para apartar cualquier atisbo de irregularidad, recaía sobre el Santo Oficio-; la averiguación retrospectiva de los orígenes se había establecido en la cuarta generación, y Juan Antonio es probable que, dada la evidencia, no estuviese dispuesto a asumir los riesgos que comportaba, no tanto para su hacienda como para su propia honra y proyección social, la constatación de su mezcolanza con la sangre hebrea (Gil, 2000: 2: 132-138). Las sospechas debían de ser, además, y para mayor vergüenza de Juan Antonio, vox populi, lo cual se deja traslucir claramente en un documento manuscrito contemporáneo al autor, dado a la luz por Pedro Ruiz Pérez (2006), perteneciente a un tal Fiscal Parnaso, en el que este realiza varias alusiones a sus antecedentes judaizantes; la carta no fue objeto de respuesta por parte de Vera, lo cual pudiera interpretarse como una tácita confirmación de su origen indigno ${ }^{35}$.

Fernando murió en Mérida, patria de su padre y sus abuelos, en octubre de $1640^{36}$, apenas tres meses después de la citada denuncia ante el visitador Francisco de Quevedo. La sangre hebrea quedaba ya totalmente extinguida en la estirpe de los Vera; realizar una conexión entre una muerte a una edad tan temprana con el desprestigio que sin duda ocasionaría para el conde de la Roca la existencia de un hijo con una sospechosa ascendencia judía, unida al anterior incidente conventual, no deja de ser una hipótesis, pero los escasos datos que conocemos de la vida del primogénito del conde de la Roca nos obligan a que nos movamos en el campo de las conjeturas. Su padre, que permanecía en Italia como embajador de Venecia desde 1632, se enteraría de su fallecimiento por carta. La Real Academia de la Historia de Madrid conserva el cenotafio que tras su muerte realizó el emeritense Juan Gómez Bravo ${ }^{37}$, ca-

${ }^{34}$ Sobre los requisitos de limpieza de sangre para el acceso a determinados cargos eclesiásticos, así como el reflejo que se daba en los conventos de ese exclusivismo social que dominó los inicios del siglo XVII, vid. Bartolomé Bennassar (2004: 174-175). Albert A. Sicroff (1985: 264 y ss.) destaca la influencia que obras como el Tractatus bipartitus de puritate de Juan Escobar del Corro (que interpretaba ideas contenidas en Aristóteles, santo Tomás de Aquino y san Agustín) ejercieron sobre la consolidación de la creencia popular de que - y avanzándose a las teorías genéticas de Mendel - la herencia biológica de aquellos rasgos fisiológicos y morales que se consideraban característicos de los judíos se transmitían a través de varias generaciones (incluso a través de la leche materna).

${ }^{35}$ Pedro Ruiz Pérez ofrece la primera edición de dicha respuesta, junto a un estudio introductorio en el que analiza las conexiones, en clave de burla, con la obra de Vera.

${ }^{36} \mathrm{El}$ acta de defunción, con fecha de 28 de octubre de 1640, se encuentra en la parroquia de Santa María de Mérida.

${ }^{37}$ Gómez Bravo alaba la virtud y el incomparable ingenio de Fernando y se lamenta de su muerte a los 41 años. El epitafio está fechado en las calendas de noviembre de 1640. En 1642, unos meses después de la muerte de Fernando, Juan Gómez dedica una breve historia de Mérida (publicada en Sevilla) a Fernando Carlos de Vera y Figueroa, vizconde de Sierrabrava. 
pellán de la catedral de Sevilla y amigo del conde de la Roca, a quien había dedicado su obra Advertencias a la Historia de Mérida (Florencia, 1638).

\subsection{Una autoría problemática}

Fernando de Vera publicó su primera obra, el Panegírico por la poesía, en 1627; según figura en el colofón, se daba a la luz en la ciudad de Montilla (Córdoba), por el impresor Manuel de Payva. La obra carecía de los requisitos exigidos por la Pragmática de Valladolid de 1558, vigente en ese momento, que exigía como requisito de impresión ${ }^{38}$ que en el libro figurasen la licencia, la tasa, el privilegio (si lo había), el nombre del autor e impresor y el lugar de impresión. Además, desde 1605 sería obligatorio que los libreros llevasen un inventario de los libros que guardasen en su establecimiento y, además, que realizasen un control sobre las ventas, ya que en dicho inventario debía consignarse asimismo el nombre de los clientes que adquirían los libros; dicha regulación sobre el comercio del libro, de carácter prescriptivo, será ratificada en el Index de 1612, en el «Mandato a los libreros, corredores y tratantes de libros», y posteriormente, en 1620, con nuevas obligaciones para los libreros. Precisamente en 1627, una nueva ley ordenaba «no dexar que se impriman libros no necesarios ó convenientes, ni de materias que deban ó puedan excusarse, ó no importe su lectura; pues ya hay demasiada abundancia de ellos», y establecía la exigencia de consignar con exactitud el nombre del autor, del impresor y la fecha exacta de edición ${ }^{39}$.

\footnotetext{
${ }^{38}$ A pesar de que las primeras medidas legislativas de los reinos de Castilla y Aragón referentes a la impresión y venta de libros eran extremadamente liberales, lo cual favorecía la implantación de imprentas locales e importación de libros extranjeros, el 8 de julio de 1502 aparece la primera disposición legal que obligaba a solicitar licencia tanto para la impresión de libros en España como para la introducción de libros extranjeros, estableciéndose de esta manera la censura previa a la impresión (Kamen, 1979: 100-101), que contaba ya con antecedentes en Europa (Bujanda, 1984: 33), ya que —como destaca José Simón Díaz-, antes de que los Reyes Católicos encomendasen a diversos prelados la censura en materia de libros, ya el papa había proclamado el derecho y el deber de la Iglesia católica a ocuparse de ella (1983: 21-29). En 1554, una nueva disposición reducía el número de licencias de impresión, para evitar la publicación de libros inútiles y sin provecho alguno (Bujanda, 1984: 35), pero va a ser la ley pragmática de Valladolid de 1558 la que imponga importantes restricciones a la impresión y comercio de libros. Dicha ley, de extremada dureza - hecho que le valió el calificativo de «ley de la sangre»-, declaraba una verdadera guerra al libro, al establecer una censura previa y posterior a la impresión.

${ }^{39}$ Ley de 13 de junio de 1627 (Simón Díaz, 1983: 11). Sobre la descripción científica de los preliminares, vid. Anne Cayuela (1996). Sobre los paratextos y requisitos de impresión en las obras del Siglo de Oro puede consultarse el artículo de Ignacio García Aguilar titulado «De Trento al Parnaso: aprobación textual y sanción poética en los poemarios impresos del XVI» (2008), así como su obra Imprenta y literatura en el Siglo de Oro. La poesía de Lope de Vega (2006).
} 
Sin embargo, el ejemplo que nos ocupa es una muestra palpable de la falta de operatividad de los controles ejercidos por el Santo Oficio, especialmente a medida que nos alejamos del expurgatorio de 1612 y su apéndice de 1614, que convirtió en práctica habitual la expurgación, por lo que la Inquisición se vio desbordada y hubo de acudir a personas ajenas al aparato inquisitorial, comenzando de esta manera una progresiva decadencia en la eficacia del control $^{40}$. En 1627, el control sobre el comercio del libro era desigual, con un menor apogeo en imprentas de ámbito local; así, por citar un ejemplo opuesto al que nos ocupa, las Obras en verso del Homero español - primera edición del cordobés Luis de Góngora-, recogida por Juan López de Vicuña, habían sido impresas en Madrid en diciembre de 1627, y fueron retiradas rápidamente por el Santo Tribunal bajo el pretexto - entre otras razones- de publicarse sin el «verdadero nombre del autor» ${ }^{41}$. Sin embargo, existen otros ejemplos en los que, sin estar motivados por razones personales - como en el caso de las obras de Luis de Góngora- la medida inquisitorial no se obedecía de forma tan inflexible ${ }^{42}$.

El Panegírico por la poesía podría haber sido apartado de la libre circulación — cosa que no ocurrió-, al quebrantar la mayoría de las disposiciones de la ley pragmática de 1558. Según esta, debía obtenerse legalmente una licencia del Consejo Real para la impresión del libro; en el examen que el censor realizara de la obra, debía presentar ante dicho consejo un ejemplar con las correcciones o expurgaciones. El libro debía imprimirse sin portada ni preliminares, para cotejarlo posteriormente con el ejemplar depositado en el Consejo Real, que finalmente aprobaría el precio de venta de cada pliego; por último, se imprimía la portada y los preliminares, que debían contener la li-

${ }^{40}$ José Pardo Tomás (1991) ha señalado cuatro etapas, según el mayor o menor apogeo de estos sistemas de control: un período de desarrollo (1559-1584), un período de plenitud (1584-1612), un período de madurez y de crisis (1612-1640), que finaliza con la aparición del Novissimus Index en 1640, que da inicio al período de decadencia.

${ }^{41}$ Artículo octavo del informe del padre Pineda, trasladado por Joaquín de Entrambasaguas, en Estudios y ensayos sobre Góngora y el Barroco (1975: 114-123). Sin embargo, el primer dictamen de censura, realizado por el padre Hernando Horio, no había resultado tan extremado con las obras del cordobés; mas la obra fue objeto de delación — probablemente por parte de Francisco de Quevedo, que pretendía ver no solo muerto, sino exterminado a su rival—, cuyo artífice sugirió la revisión de la obra al padre Pineda, con el que el poeta cordobés se había enemistado en 1610 a raíz de una justa poética en la que, no saliendo premiado un soneto suyo, respondió a Pineda, uno de los jueces, con un soneto satírico que lo ridiculizaba por su color de pelo denominándolo «padre azafranado» y atacaba la obra sobre Job que el fraile había escrito. Pineda se vengó atacando más de treinta pasajes del libro y dedujo que las indecencias que en él se contenían eran la prueba por la que el autor no había otorgado su consentimiento para que sus obras fueran publicadas en vida, y por ello también no figuraba su nombre en portada.

42 Así, en 1573 había aparecido una edición expurgada del Lazarillo de Tormes, obra que, como hasta la fecha, salía sin el nombre del artífice. 
cencia de impresión, la tasa, el privilegio (si lo había), el nombre del autor ${ }^{43}$ y del impresor. En la portada del Panegírico solo figuraba el título; el nombre del autor había sido sustituido por el escudo de la casa de los Vera, hecho que, por otro lado, daría lugar a la ambigüedad en su atribución, ya que dicho escudo sería utilizado por otros miembros de la familia. Así, había aparecido en 1620 en la portada de El Embajador de Juan Antonio de Vera, en la que dicho águila se exhibía en el frontispicio de la obra, rematando un arco triunfal barroco, y también aparecería en el Tratado breve de la antigüedad del linaje de Vera (Lima, 1635), obra atribuida al obispo de Bujía, tío de Fernando, que se publicó bajo el seudónimo de Francisco de la Puente.

Homero Serís, en el estudio introductorio realizado para la edición facsímil del Panegírico de 1968 explicaba por razones de modestia o timidez el hecho de que la obra hubiese sido publicada sin el nombre de su autor. Está claro que las disposiciones legales estaban por encima de cualquier atisbo de modestia, y que la obra se publicó anónima por otras razones, y que probablemente tampoco tenían nada que ver con su contenido, puesto que la obra no atentaba contra la Iglesia, el estado, la moral ni las buenas costumbres. Creemos que detrás de esta anonimia puede haber - conforme a lo que hemos apuntado anteriormente-, razones de defensa del linaje, ya que el propio Juan Antonio de Vera debía de preferir que su hijo permaneciese en el olvido; quizá por ello pudiera haber sido el propio Juan Antonio el que, sin el consentimiento de su hijo, diese a una imprenta alejada de Sevilla — de forma que Fernando no lograra enterarse hasta ya finalizada la edición- el encargo de impresión de una obra que ponía en relación el mundo de las letras y la poesía con la figura del conde-duque de Olivares, al que tenía especial interés en alabar su contribución a dicho mundo, puesto que de aquel dependía la consecución del tan ansiado título de conde de la Roca, que por fin pudo conseguir precisamente en el año 1628. Creemos que no es una mera coincidencia y que debió de tener una gran relación la fecha de publicación del Panegírico con la obtención del tan anhelado título. Nos inclinamos, pues, a opinar, que fue el propio padre el que retocó la obra comenzada por el hijo en - si hacemos caso a sus propias palabras - 1616. La obra contiene datos de acontecimientos acaecidos en 1626. El hecho de que el autor no reconozca en el prólogo este hecho, pero sí dé a entender que la obra estaba acabada cuando él contaba tan solo diecisiete años puede tener como base el tópico de la falsa modestia, de larga trascendencia en nuestra literatura, con el que el autor, a través de una presentación humilde en el prólogo, pretende después deslumbrar con un extenso aparato erudito, como es el caso que nos ocupa.

El libro carece además de tasa y fe de erratas; dicha ausencia de tasa

${ }^{43}$ La obligación de consignar la fecha de impresión es nueva exigencia de la Ley de 13 de junio de 1627, en la que también se hacía especial hincapié en que debían señalarse con exactitud el nombre del autor (sin seudónimo) y del impresor (Pérez Priego, 1997: 39). 
implica que la intención prioritaria de la persona que encargó la edición no era lucrarse. Por otro lado, solo aparece la aprobación de la autoridad religiosa, a cargo del padre fray Juan de Vitoria, catedrático de Escritura de la Universidad de Osuna ${ }^{44}$, quien alaba los méritos de la obra utilizando como argumento de autoridad el hecho de que hacía unos años esos mismos papeles habían sido aprobados por Lope de Vega Carpio, esa vez con nombre de su autor. La aprobación lleva fecha de 29 de enero de $1627^{45}$, pero desconocemos la datación exacta en que el libro salió de imprenta; sin embargo, teniendo en cuenta que la publicación de la obra fue objeto de respuesta manuscrita (bajo el seudónimo de Fiscal Parnaso), fechada esta «el mes de la canícula, el año del Panegírico», la salida de la imprenta de aquella puede datarse entre los meses de marzo a mayo de 1627. Los preliminares también carecen de la aprobación de la autoridad civil. Resulta curioso, por tanto, que no se guardasen las primeras aprobaciones.

Fernando de Vera pudo haber encargado en 1620 la edición de su Panegírico por la poesía a Luis Estupiñán, impresor que trabajó — tras una etapa portuguesa- en Sevilla, desde 1610 hasta 1614, año en el que interrumpió su actividad editorial para reanudarla precisamente en el 1620, fecha de ese primer proyecto editorial de Vera, y al que le pudo unir aficiones literarias. Juan Delgado Casado afirma que entre 1612 y 1615, Estupiñán había realizado impresiones de gran calidad ${ }^{46}$, algunas para el convento de San Agustín de Sevilla (donde residía Vera), y tras una etapa de declive económico vuelve a estar activo desde 1620 hasta 1633, pero ya realizando obras de menor envergadura y calidad de impresión (1996: 1: 210-211; Domínguez Guzmán, 1992: 24). Quizá también Estupiñán mantuvo relaciones de amistad con Serrano de Vargas y Botello de Payva —este último había tenido, como él, relación con Portugal-, pues los tres coincidieron durante algún tiempo en Sevilla y realizarían trabajos - aunque a distintos tiempos— en Écija y Osuna (Delgado Casado, 1996: 2: 777 y 786).

${ }^{44}$ Universidad menor fundada en 1548, a la que Cervantes hará objeto de varias burlas en la segunda parte de El Quijote (cap. I y XLVII). Será asimismo uno de los motivos de ataque de Fiscal Parnaso en su respuesta al Panegírico (Ruiz Pérez, 2006: 483).

${ }^{45} \mathrm{El}$ hecho de que la obra la aprobase el catedrático de la Universidad de Osuna, y no un religioso del lugar en que residía Fernando de Vera, pudo deberse al hecho de que Vera no contase con el visto bueno de los superiores de la orden agustina, un hecho que también podría ser explicativo de la ausencia del nombre del autor; un auto del Consejo de 3 de julio de 1626 negaba la licencia para imprimir aquellas obras de religiosos que no contasen con la aprobación de sus superiores. La desobediencia de Vera quedaría de esta manera más que manifiesta. Un caso similar es el de Baltasar Gracián, quien publicaría sus obras (a excepción de El Comulgatorio, único libro que reconoció como legítimo) bajo seudónimo con el propósito de evitar la censura de la orden de los jesuitas, a la que pertenecía.

${ }^{46}$ Estupiñán fue uno de los escasos impresores que utilizaron marca de imprenta en el siglo XVII, la cual fue utilizada asimismo por Ramos Bejarano (Escudero y Perosso, 1894: 38-39). 
Por otro lado, no deja de resultar llamativa la elección del lugar de edición de la obra. La familia Vera no tenía ningún tipo de contacto con la ciudad cordobesa, si bien en Montilla había un convento de frailes de la orden agustiniana (fundado en 1520), a los que pudiera habérsele encargado la edición. Sin embargo, creemos que la impresión en dicha ciudad se debió, por un lado, a razones de amistad con el impresor, de origen portugués, Manuel de Payva, que tenía contactos con la ciudad de Osuna ${ }^{47}$, lugar donde se realiza la aprobación del Panegírico, y con Sevilla, ciudad de la que recibe la mayoría de sus encargos ${ }^{48}$, como es el caso del Tratado y relacion del auto

${ }^{47}$ En 1629-1630 Payva imprimió en Osuna la obra de Hipólito de Vergara Del Santo rey D. Fernando, de la Santísima Virgen de los Reyes, manteniendo mientras tanto inactivo su taller en Antequera.

${ }^{48}$ Manuel Botello de Payva - Manuel de Payva en los documentos notariales- se afinca en Sevilla a comienzos del siglo XVII. Allí trabajó como ayudante en la imprenta de Gabriel Ramos Bejarano, uno de los más prolíficos impresores sevillanos del primer tercio del XVII. Ramos Bejarano se desplazó desde Sevilla hasta Córdoba a instancias de Francisco Roberte, quien había recibido un encargo del humanista e historiador cordobés Ambrosio de Morales para la publicación de la tercera parte de su Crónica y para la edición de las obras de Fernán Pérez de Oliva, y para ello trae al impresor sevillano Gabriel Ramos, que establece en Córdoba la primera imprenta permanente (Pérez de Oliva, 1982). Gabriel Ramos imprime en Córdoba, en 1586, Los Cinco libros postreros de la Coronica general de España, obra de Ambrosio de Morales, y Las obras del Maestro Fernan Perez de Oliua natural de Cordoua, ambas a costa de Francisco Roberte, y permanece en dicha ciudad hasta 1602, año en el que regresa a Sevilla, donde sigue trabajando como impresor, con importantes encargos como la publicación de los Versos de Fernando de Herrera: emendados y divididos por él en tres libros (1619). Uno de esos encargos fue el del montillano Juan Bautista de Morales, autor de la Jornada de Africa del rey don Sebastian de Portugal (1622), en cuya imprenta conoció a su ayudante Manuel de Payva, de orígenes portugueses. No tenemos constancia si sobre la figura de Manuel de Payva existieron sospechas de antecedentes judíos, mas teniendo en cuenta que Portugal fue durante muchos años - tras la expulsión de los Reyes Católicos de 1492- asilo de judíos (y más concretamente Évora), es probable que en sus venas corriese sangre conversa, y que decidiese emigrar a Sevilla, alejada ya, después de un siglo, la truculencia de las primeras persecuciones. Bautista de Morales también conocía el portugués (en 1622 publicó, ya en su propia imprenta, una traducción del portugués al castellano de la obra de Francisco Rodríguez Lobo titulada Corte en aldea y noches de invierno), y en octubre de 1622 contrató a Manuel de Payva para que durante un año trabajara en su taller montillano. Finalizado el contrato de impresión, Payva establece su propia imprenta en Montilla, que compite con la del marqués de Priego y con la propia de Juan Bautista de Morales. A finales de 1627 Payva se traslada a Antequera, donde continúa teniendo encargos sevillanos, hasta su fallecimiento en 1635. El nombre de Payva no aparece ni en la Tipografía hispalense de Escudero y Perosso ni en La imprenta en Sevilla. Noticias inéditas de sus impresores desde la introducción del arte tipográfico en esta ciudad hasta el siglo XIX (1945) de Joaquín Hazañas y La Rúa. Por otro lado, Aurora Domínguez destaca de Ramos Bejarano su descuido en la impresión, con errores en la foliación incluso en los impresos breves, desaliño del que se pudo haber contagiado Payva: recordemos que al Panegírico le falta un período (el doceavo), sin que conozcamos si esta laguna fue debida a alguna pérdida, despiste en la numeración o tal vez a ineptitud del impresor (1992: 24). 
publico de fee que se hizo en la ciudad de Sevilla... (1625), de Alonso de Ginete; de todos estos encargos, sin duda el más importante, y también el más extenso, fue el Panegyrico por la poesia, que constaba de 59 folios y cinco hojas con la «Resvnta deste Panegyrico» (índice de materias), y al final el colofón. La actividad de Manuel de Payva como impresor en Montilla había aumentado en 1626, año en que recibe un encargo del propio ayuntamiento de la villa que lo lleva a autocalificarse como «Impressor del Cabildo» ${ }^{49}$. Una segunda razón por la que pudo elegirse la capital del marquesado de Priego para la impresión del Panegírico pudo estar relacionada con la opinión que acerca de esta imprenta tenía el impresor sevillano Juan Serrano de Vargas; celoso quizá de que algunos de los encargos sevillanos fuesen a parar a imprentas alejadas de la ciudad hispalense, decía lo siguiente:

En Montilla lugar de pocos vezinos, y de cuatro hombres de letras medianas, ay dos impressores que son frente de mil inventivas y disparates que imprimen y cunden el andaluzía. En cádiz ay otro y en xerez otro y en málaga dos, donde no los huuo jamás, ni pueden sustentarse, y assí quando uno quiere imprimir algo en ofensa o defensa acude a éstos, que ven el cielo abierto, $[\ldots]^{50}$.

Para Pedro Ruiz Pérez la ubicación geográfica de Montilla hacía de esta ciudad un lugar estratégico, tanto por su proximidad con Córdoba, Sevilla y

${ }^{49}$ Se trata de un impreso realizado por encargo del alcalde de la villa, que se realizaba en aplicación del Pregon en que sv magestad manda, qve las mercaderias de qualquier genero que sean, y demas cosas en el contenidas, no se puedan vender, ni vendan a mas subidos precios de como passauan, y se vendian el año passado de mil y seyscientos y veinte y quatro, so las penas en el declaradas, a instancias de Fernando de Vallejo, secretario del rey y su escribano de cámara (1626). Como respuesta inmediata a dicho pregón, el 13 de junio de 1626 el alcalde de la villa dicta ante escribano el correspondiente mandato, que lo imprime Payva dos días después, con el título «(...) Mándo a los Mercaderes de esta Villa, guarden en el vender de las Mercaderias los Precios siguientes», y le sigue una relación de productos y precios a los que debían venderse, fechado «en 15. de Iunio del Año de 1626. Impresso en Montilla, Por Manuel Botello de Payua, Impressor del Cabildo» (Archivo Histórico Municipal de Montilla, Leg. 1168B, exp. 2). Sin embargo, la situación económica de Payva no era muy holgada, puesto que en julio de 1627 contraía mediante escritura notarial un préstamo con el mercader Francisco Álvarez (Archivo de Protocolos Notariales de Montilla, escribanía de Francisco Escudero, leg. 51, fol. CCCVI).

${ }^{50}$ Memorial dado por Joan Serrano de Barrgas Maestro impresor de libros en Sevilla en Julio de 1625 sobre los excesos en materia de libro, en el que además acusa al librero Alonso Pérez de imprimir libros prohibidos por el Santo Oficio (Cayuela, 2005: 126). El manuscrito, conservado en la Biblioteca Nacional de Madrid, fue transcrito por Jesús Domínguez Bardona en la Revista de Archivos, Bibliotecas y Museos (1926). El texto citado procede de Fernando Bouza (1998: 37), que data el manuscrito en julio de 1628, si bien otros autores consultados (Luis Méndez Rodríguez, Carmen Castañeda Rodríguez, Pedro J. Rueda Ramírez, Alfredo Alvar Ezquerra, etc.) lo datan en julio de 1625. Juan Serrano de Vargas había impreso en 1622 para la Universidad de Osuna; imaginamos que no le causaría grata sorpresa cuando tuviese constancia de que una obra sevillana, con aprobación de un catedrático de dicha universidad, había ido a parar a prensas montillanas. 
Osuna, como por permitir — dada su situación en una relativa periferia- este tipo de impresos que rayaban la clandestinidad (2006: 458-459).

En definitiva, las difíciles relaciones entre el conde de la Roca y su primogénito, vinculadas con cuestiones de limpieza de sangre en el linaje materno, propiciaron que Juan Antonio proyectase para su hijo una vida a su sombra, recluida en un monasterio y alejada de la ostentación a la que él era tan proclive. Juan Antonio pudo haber aprovechado una obra realizada por su hijo durante su etapa de formación en el colegio de los agustinos para, años más tarde, realizar toda una manipulación editorial que comenzaría con una serie de interpolaciones con las que pretendía ofrecer una imagen atractiva de sí mismo, que le facilitaba su ascenso en la escala social, requisito para la consecución del tan ansiado título de conde de la Roca, conseguido apenas un año después de la publicación del Panegírico por la poesía, y finalizaba con una planificada anonimia de la obra, cuya consecuencia más inmediata sería su publicación en una edición casi clandestina y desprendida de cualquier atisbo de legalidad, así como su impresión en un lugar periférico. Sin embargo, su publicación en una fecha estratégica, como fue la de la primera edición de las obras de Luis de Góngora, ha sido motivo más que suficiente para vincular esta obra con la teoría poética del momento.

\section{BIBLIOGRAFÍA CITADA}

Alonso, Dámaso y Rafael Ferreres (eds.) (1950). Cancionero antequerano recogido por los años de 1627 y 1628 por Ignacio de Toledo y Godoy. Madrid: CSIC.

Antonio, Nicolás (1783). Bibliotheca Hispana Nova, Tomus Primus. Matriti: apud Joachimum de Ibarra typographum regium.

Barrera y Leirado, Cayetano Alberto de la (1860). Catálogo bibliográfico y biográfico del teatro antiguo español desde su origen hasta mediados del siglo XVIII. Madrid: Imprenta y estereotipia de M. Rivadeneyra.

Bennasar, Bartolomé (2004). La España del Siglo de Oro. Barcelona: Crítica.

Blanco, Mercedes (2011). «El Panegírico al duque de Lerma como poema heroico», en Jesús Matas Caballero, José María Micó y Jesús Cárdenas (dirs.), El duque de Lerma. Poder y literatura en el Siglo de Oro. Madrid: Centro de Estudios Europa Hispánica, pp. 11-56.

Bouza, Fernando (1998). Imagen y propaganda. Capítulos de historia cultural del reinado de Felipe II. Madrid: Akal.

Bujanda, J. M. de (1984). Index de l'Inquisition espagnole, 1551, 1554, 1559. Sherbrooke (Canadá): Centre d'Études de la Renaissance.

Calvo López-Guerrero, Gabriel (1993). Edición y estudio del Panegírico por la poesía (1627), atribuido a Fernando Luis de Vera y Mendoza. Ciudad Real: Universidad de CastillaLa Mancha (tesis doctoral inédita).

Cardenal de Iracheta, Manuel (1941). «El Panegírico por la poesía de D. Fernando Luis de Vera y Mendoza», Revista de Bibliografía Nacional. II, núm. $3^{\circ}$ y $4^{\circ}$, pp. 265-342.

Castilla (Reino), Cortes (1861). Actas de las Cortes de Castilla: contiene las de Madrid, celebradas el año 1563. Vol. I. Madrid: Imprenta Nacional. 
Cayuela, Anne (1996). Le paratexte au Siècle d'Or: prose romanesque, livres et lecteurs en Espagne au XVIIe siècle. Genève: Droz.

Cayuela, Anne (2005). Alonso Pérez de Montalbán. Un librero en el Madrid de los Austrias. Madrid: Calambur.

Curtius, Ernst Robert (1939). «Theologische Kunsttheorie im spanischen Barok», Romanische Forschungen. 53, 2, pp. 145-184.

Curtius, Ernst Robert (1955, $2^{\mathrm{a}}$ reimpr. 1976). Literatura europea y Edad Media latina. Vol. II. Trad. Margit Frenk Alatorre y Antonio Alatorre. México: Fondo de Cultura Económica.

Delgado Casado, Juan (1996). Diccionario de impresores españoles (siglos XVI-XVII), 2 vols. Madrid: Arco / Libros.

Domínguez Guzmán, Aurora (1992). La imprenta en Sevilla en el siglo XVII (Catálogo y análisis de su producción, 1601-1650). Sevilla: Universidad de Sevilla.

Domínguez Ortiz, Antonio (1986). Historia de Sevilla: la Sevilla del siglo XVII. Sevilla: Universidad de Sevilla.

Domínguez Ortiz, Antonio (1999). «Sevilla y Felipe II», en Carlos Alberto González Sánchez (ed.), Sevilla, Felipe II y la Monarquía hispánica. Sevilla: Ayuntamiento de Sevilla, pp. 19-31.

Elliot, John H. (1998). El Conde-Duque de Olivares. El político de una época de decadencia. Trad. Teófilo de Lozoya. Barcelona: Grijalbo Mondadori.

Entrambasaguas, Joaquín de (1975). Estudios y ensayos sobre Góngora y el Barroco. Madrid: Editora Nacional.

Escudero y Perosso, Francisco (1894). Tipografía Hispalense: Anales Bibliográficos de la ciudad de Sevilla desde el establecimiento de la imprenta hasta fines del siglo XVIII. Madrid: Sucesores de Rivadeneyra.

Fernández-Daza Álvarez, Carmen (1994). «Noticias inéditas de la vida de fray Fernando de Vera y Mendoza», Revista de Estudios Extremeños. L, núm. 1, pp. 87-105.

Fernández-Daza Álvarez, Carmen (1995). El primer conde de la Roca. Mérida: Editora Regional de Extremadura.

Fernández-Guerra y Orbe, Aureliano (1864). Noticia de un precioso códice de la Biblioteca Colombina; algunos datos nuevos para ilustrar El Quijote. Madrid: imprenta y estereotipia de M. Rivadeneyra.

Francknau, Gerhardus Ernestus de (1724). Bibliotheca hispanica historico-genealogicoheraldica. Lipsiae: sumptibus Maur. Georgii Ewidmanni.

García Aguilar, Ignacio (2006). Imprenta y literatura en el Siglo de Oro. La poesía de Lope de Vega. Madrid: Ediciones del Orto.

García Aguilar, Ignacio (2008). «De Trento al Parnaso: aprobación textual y sanción poética en los poemarios impresos del XVI», en Begoña López Bueno (dir.), El canon poético en el siglo XVI. Sevilla: Universidad de Sevilla, pp. 235-256.

García Fuentes, Lutgardo (1997). Los peruleros y el comercio de Sevilla con las Indias, 15801630. Sevilla: Universidad de Sevilla.

García García, Bernardo José (1999). El ocio en la España del Siglo de Oro. Madrid: Akal.

Gil, Juan (2000). Los conversos y la Inquisición sevillana. Vol. I y II. Sevilla: Universidad de Sevilla.

Gregorio Vela, Santiago de (1915). Ensayo de una biblioteca ibero-americana de la orden de San Agustí. Madrid: Imprenta del Asilo de Húerfanos del S. C. de Jesús.

Kamen, Henry (1979). La Inquisición española. Barcelona: Crítica.

Lleó Cañal, Vicente (1979). Nueva Roma: mitología y Humanismo en el Renacimiento sevillano. Sevilla: Diputación Provincial de Sevilla.

López Bueno, Begoña (coord.) (2006). La renovación poética del Renacimiento al Barroco. Madrid: Síntesis. 
Lozano Bartolozzi, Ma del Mar (1997). «Los conventos de Mérida en la historia moderna. Fundaciones, supervivencia, transformación, ruina y reutilización», Norba-Arte. XVII, pp. 121-148.

Madoz, Pascual (1849). Diccionario geográfico-estadístico-histórico de España y sus posesiones de ultramar. Vol. 14. Madrid: imprenta del Diccionario geográfico, estadístico, histórico de Pascual Madoz.

Madroñal Durán, Abraham (2009). Humanismo y filología en el Siglo de Oro. En torno a la obra de Bartolomé Jiménez Patón. Madrid: Iberoamericana.

Marañón, Gregorio (1936, 26ª ed. 1998). El Conde-Duque de Olivares: la pasión de mandar. Madrid: Espasa-Calpe.

Martín Ruiz, José María (1993). «Maquiavelo y el tacitismo en la España de los siglos XVI y XVII», Baética: estudios de arte, geografía e historia. 15, pp. 317-328.

Martínez de la Vega, Ma Elisa (1994). «El convento clariano de la Concepción de Mérida: paradigma de fundación pía no autónoma», Espacio, Tiempo y Forma, Serie IV, Historia Moderna. T. 7, pp. 11-28.

Menéndez y Pelayo, Marcelino (1994). Historia de las ideas estéticas en España. Vol. II. Madrid: CSIC.

Mesonero Romanos, Ramón de (1859). Dramáticos posteriores a Lope de Vega. Vol. 2. Madrid: Impresor y editor M. Rivadeneyra.

Molina Huete, Belén (2003). La trama del ramillete. Construcción y sentido de las «Flores de poetas ilustres» de Pedro de Espinosa. Sevilla: Fundación José Manuel Lara.

Montiano y Luyando, Agustín de (1753). Discurso II. sobre las tragedias españolas. Madrid: Imprenta del Mercurio, por Joseph de Orga, impressor.

Moreno de Vargas, Bernabé (1633). Historia de la civdad de Merida. Dedicada a la mis ma. Madrid: viuda de Alonso Martín.

Núñez Roldán, Francisco (2004). La vida cotidiana en la Sevilla del Siglo de Oro. Madrid: Sílex.

Olmos Gómez, Paula (2010). Los negocios y las ciencias: lógica, argumentación y metodología en la obra filosófica de Pedro Simón Abril (ca. 1540-1595). Madrid: CSIC.

Palau y Dulcet, Antonio (1948). Manual del librero hispanoamericano (Bibliografía general española e hispanoamericana desde la invención de la imprenta hasta nuestros tiempos con el valor comercial de los impresos descritos). Vol. 7. Barcelona: Librería anticuaria de A. Palau.

Pardo Tomás, José (1991). Ciencia y censura. La Inquisición española y los libros científicos en los siglos XVI y XVII. Madrid: CSIC.

Pérez de Oliva, Fernán (1982). Diálogo de la dignidad del hombre. Ed. M ${ }^{\mathrm{a}}$ Luisa Cerrón Puga. Madrid: Editora Nacional.

Pérez Priego, Miguel Ángel (1997). La edición de textos. Madrid: Síntesis.

Porqueras Mayo, Alberto (1989). La teoría poética en el Manierismo y Barroco españoles. Barcelona: Puvill.

Puente, Francisco de la (1635). Tratado breue de la antigüedad del linaje de Vera, y memoria de personas señaladas del, que se hallan en historias, y papeles autenticos. Lima: por Geronymo de Contreras.

Rioja, Francisco de (1984). Poesía. Ed. Begoña López Bueno. Madrid: Cátedra.

Roldán Paz, Lorena (2004). «Control de conciencias en la periferia: visitas inquisitoriales a la ciudad de Antequera en el siglo XVII», Baetica. Estudios de Arte, Geografía e Historia. 26, pp. 369-388.

Ruiz Pérez, Pedro (2003). «La poética de la erudición en Trillo y Figueroa», La Perinola. 7, pp. 335-336.

Ruiz Pérez, Pedro (2006). «Una respuesta al Panegírico por la poesía: esbozos de crítica en la Andalucía barroca», Nueva Revista de Filología Hispánica. LIV, núm. 2, pp. 453-488. 
Sánchez Ortega, María Helena (1992). La mujer y la sexualidad en el Antiguo Régimen: la perspectiva inquisitorial. Madrid: Akal.

Sicroff, Albert A. (1985). Los estatutos de limpieza de sangre: controversias entre los siglos XV y XVII. Madrid: Taurus.

Simón Díaz, José (1983). El libro español antiguo. Análisis de su estructura. Reichenberger: Kassel.

Stradling, R. A. (1989). Felipe IV y el gobierno de España, 1621-1665. Madrid: Cátedra.

Ticknor, George (1851-1856). Historia de la literatura española. Trad. Pascual de Gayangos y Enrique de Vedia. Madrid: Imprenta y estereotipia de M. Rivadeneyra.

Velázquez de Velasco, Luis José (1754). Orígenes de la poesía castellana. Málaga: Oficina de Francisco Martínez de Aguilar.

Vera y Mendoza, Fernando Luis de (1627). Panegyrico por la poesia. Montilla: Manuel de Payua.

Vera y Mendoza, Fernando Luis de (1631). Explicación i notas al Libro quarto del Arte, que comúnmente se enseña en las Universidades, i Escuelas de España, dispuestas por Fernando de Vera, del modo que las aprendio del Padre Agustin de Herrera. Granada: Imprenta de Martín Fernández.

Vera y Mendoza, Fernando Luis de (1631). Explicacion i notas al Libro Quinto, que el autor del Arte intitula De syllabarvm qvantitate et versificandi ratione. Granada: Imprenta de Martín Fernández Zambrano.

Vera y Mendoza, Fernando Luis de (1886). Panegírico por la poesía. Dada á luz por Manuel Perez de Guzman. Sevilla: Imp. de E. Rasco.

Vera y Mendoza, Fernando Luis de (1968). Panegyrico por la poesía. Valencia: Cieza, Colección «El ayre de la almena». Textos literarios rarísimos, XXI.

Vera y Mendoza, Fernando Luis de (1669). No hay gusto como la honra, en Parte treinta y vna de Comedias nueuas escritas por los mejores ingenios de España... Madrid: por Ioseph Fernandez de Buendia: a costa de Manuel Meléndez, pp. 148-180.

Vera y Zúñiga, Juan Antonio de (1620). El Enbaxador. Sevilla: Francisco de Lyra.

Villalba, Joaquín de (1802). Epidemiologia española: ó historia cronológica de las pestes, contagios, epidemias y epizootias que han acaecido en España desde la venida de los cartagineses hasta el año 1801. Vol. II. Madrid: Imprenta de don Mateo Repullés.

Fecha de recepción: 22 de marzo de 2012

Fecha de aceptación: 23 de octubre de 2012 